LA GRANJA:

REVISTA DE

CIENCIAS DE LA VIDA

pISSN:1390-3799; eISSN:1390-8596

http://doi.org/10.17163/lgr.n25.2017.02
Artículo científico / Scientific paper

Ciencias DE LA TIERRA

\title{
HEAVY RAINFALL AND TEMPERATURE PROYECTIONS IN A CLIMATE CHANGE SCENARIO OVER QUITO, ECUADOR
}

\author{
PROYECCIONES DE LLUVIA Y TEMPERATURA EXTREMA EN ESCENARIOS DE \\ CAMBIO CLIMÁTICO SOBRE QUITO, ECUADOR
}

\author{
Sheila Serrano Vincenti ${ }^{1, *}$, Jean Carlos Ruiz ${ }^{2}$ and Fabián Bersosa ${ }^{3}$
}

\begin{abstract}
${ }^{1}$ Grupo de Investigación en Ciencias Ambientales GRICAM, Centro de Investigación en Modelamiento Ambiental CIMA-UPS/ Universidad Politécnica Salesiana/Red de Universidades Frente al Cambio Climático y Gestión de Riesgos, Quito, Ecuador.

${ }^{2}$ Escuela Politécnica Nacional/Red de Universidades Frente al Cambio Climático y Gestión de Riesgos, Quito, Ecuador

${ }^{3}$ Grupo de Investigación en Ecología y Gestión de Áreas Protegidas, Centro de Investigación en Modelamiento Ambiental CIMAUPS/Universidad Politécnica Salesiana/Red de Universidades Frente al Cambio Climático y Gestión de Riesgos, Quito, Ecuador.
\end{abstract}

*Autor para correspondencia: sserranov@ups.edu.ec

Manuscrito recibido el 14 de noviembre de 2016. Revisado el 14 de diciembre de 2016. Aceptado el 30 de diciembre de 2016. Publicado el 31 de diciembre de 2016.

\begin{abstract}
This research analyzes daily extreme events of minimum, maximum temperatures and rain in the Metropolitan District of Quito using data of more than 30 years from the meteorological network of INAMHI (Instituto Nacional de Meteorología e Hidrología de Ecuador) using the R- ClimDex computer program. A scenario for the year 2032 combining statistical results of extreme events and physical forcing from PRECIS scenarios A2 and B2 is also presented; using the extreme value theory from extReme computer program. The results showed an increase in extreme minimum and maximum monthly temperature values in both, magnitude and frequency; and an increase in the intensity of heavy rainfall. Projections to 2022 maintain this behavior, with results that should be taken into account by policy makers and scientists due to the danger they mean for Quito's ecosystem.
\end{abstract}

Keywords: extreme values, precipitation; temperature, Metropolitan District of Quito, climate change scenarios 


\section{Resumen}

Esta investigación analiza eventos extremos a nivel diario de temperaturas mínimas, máximas y lluvias en el Distrito Metropolitano de Quito utilizando datos con más de 30 años de la red meteorológica del INAMHI (Instituto Nacional de Meteorología e Hidrología de Ecuador), y utilizando el programa R-ClimDex. Se presentan escenarios el año 2032 combinando resultados estadísticos de eventos extremos con el forzamiento físico de los escenarios A2 y B2 del modelo de cambio climático PRECIS A2 y B2, y utilizando la teoría de valores extremos del programa extReme. Los resultados mostraron un incremento en los valores mensuales mínimos y máximos de temperatura tanto en magnitud y frecuencia; además de un aumento en la intensidad de lluvias extremas. Las proyecciones para 2032 mantienen este comportamiento, con resultados que deben ser tomados en cuenta por los tomadores de decisión y científicos debido al peligro que significan para el ecosistema de Quito.

Palabras claves: valores extremos, precipitación; temperatura, Distrito Metropolitano de Quito, escenarios de cambio climático.

Forma sugerida de citar: Serrano, S., J. C. Ruiz and F. Bersosa. 2017. Heavy rainfall and temperature proyections in a climate change scenario over Quito, Ecuador. La Granja: Revista de Ciencias de la Vida. Vol. 25(1):16-32. pISSN:1390-3799; eISSN:1390-8596. 


\section{Introduction}

The last report of the Intergovernmental Panel on Climate Change (IPCC AR5, 2014) indicated that there is a change in frequency and intensity of extreme weather events such as heat waves, intense precipitation, flooding, etc., in various regions of the world as a result of global climate change. These changes are particularly important for society and the environment, since by definition, they are outside the range of usual ecosystem adaptability, and thus can lead to severe impacts in biodiversity, agriculture, health infrastructure and economic losses (García et al., 2012).

Particularly, a general increase of temperature in Latin America was reported (Samaniego et al., 2009). It was also registered an increase in temperature of one tenth of a degree per decade over the Andes (Martínez et al., 2009); studies of Ecuadorian weather have shown that the temperature is gradually increasing over the region (Vuille et al., 2008; cited in Villacis et al., 2012). And studies have shown an increase of temperature in the four regions of Ecuador (Nieto et al., 2002; Cáceres, 1998). On the DMQ Zambrano-Barragán et al. (2010), and Villacis (2008), reveal an increase of annual temperature by $0.12^{\circ} \mathrm{C}$ per decade over a period of the last 100 years.

\subsection{Extreme events indexes}

In addition to the gradual behavior of a variable such as temperature, extreme events should also be recorded. The CCI / CLIVAR / JCOMM (Expert Team on Climate Change Detection and Indices) proposed a methodology which includes the RClimDex program for study extreme events in a climate change scenario (Karl et al., 1999; Peterson, 2001).

Thus, using RClimDex over the Metropolitan District of Quito DMQ, three possible threats related to climate change were identified: the extreme values of maximum and minimum daily temperatures all over the region, and the intensity of rainfall over the 90th percentile in the south and southwest of the DMQ. This analysis was constructed using available data from weather stations of INAMHI (Instituto Nacional de Meteorología e Hidrología de Ecuador) of the past 47-48 years (except station Tomalón-Tabacundo) with 21 years, located in four points of the District (Table 1). The trends are shown in Table 2.

When studying extreme values, it is necessary to change the statistical distribution because intense climate extreme events are more frequent than expected by normal distributions (Gilleland and Watts, 2005). The National Science Foundation (NSF) through the National Center for Atmospheric Research (NCAR), the Weather and Climate Impact Assessment Science Initiative, and the NCAR Geophysical Statistics Project (GSP), have recommended the use of the Extreme Value Theorem (EVT) and developed tools for the study of extreme weather events included in a specific software called eXtreme.

Table 1. Available weather stations with daily data selected for the study. ${ }^{\dagger}$ Cotopaxi-Clirsen station not presented continuous data.

\begin{tabular}{|c|c|c|c|c|c|c|c|}
\hline Station & Code Station & Latitude & Longitude & Altitude (m.a.s.l.) & From & To & Temporal range \\
\hline Izobamba & M003 & $0^{\circ} 22^{\prime} \mathrm{S}$ & $78^{\circ} 33^{\prime} \mathrm{W}$ & 3058 & 1964 & 2011 & 47 \\
\hline Papallacta & M188 & $0^{\circ} 21^{\prime} 54^{\prime \prime} \mathrm{S}$ & $78^{\circ} 8^{\prime} 41^{\prime \prime} \mathrm{W}$ & 3150 & 1963 & 2011 & 48 \\
\hline Tomalón-Tabacundo & MA2T & $0^{\circ} 2^{\prime} \mathrm{N}$ & $78^{\circ} 14^{\prime} \mathrm{W}$ & 2790 & 1990 & 2011 & 21 \\
\hline${ }^{\dagger}$ Cotopaxi-Clirsen & M120 & $0^{\circ} 37^{\prime} 24^{\prime \prime} \mathrm{S}$ & $78^{\circ} 34^{\prime} 53^{\prime \prime} \mathrm{W}$ & 3510 & 1964 & 2011 & 47 \\
\hline
\end{tabular}


Table 2. Annual trends of each R-Climdex indicator of climate change for extreme temperatures and precipitation for the four weather stations of DMQ and surroundings, ${ }^{*}$ mean values with a significance superior to $90 \%(\mathrm{p}<0.2)$.

\begin{tabular}{|c|c|c|c|c|}
\hline INDEX & $\begin{array}{c}\text { Izobamba } \\
\text { M003 }\end{array}$ & $\begin{array}{c}\text { Papallacta } \\
\text { M121 }\end{array}$ & $\begin{array}{c}\text { Tomalón-Tabacundo } \\
\text { M188 }\end{array}$ & $\begin{array}{c}\text { Cotopaxi-Clirsen } \\
\text { MA2T }\end{array}$ \\
\hline $\begin{array}{l}\text { Maximum daily minimum tem- } \\
\text { perature }\left[{ }^{\circ} \mathrm{C} / \text { year }\right](\mathrm{TNx})\end{array}$ & $0.03^{*}$ & 0.095 & $0.067^{*}$ & 0.051 \\
\hline p-value & 0 & 0.404 & 0.033 & 0.243 \\
\hline $\begin{array}{l}\text { Maximum daily maximun tem- } \\
\text { perature }(\mathrm{TXx})\left[{ }^{\circ} \mathrm{C} / \text { year }\right]\end{array}$ & $0.01^{*}$ & - & $0.031^{*}$ & $0.125^{*}$ \\
\hline p-value & 0.2 & & 0.11 & 0.001 \\
\hline $\begin{array}{l}\text { Number of heavy precipitation } \\
\text { days (greater than } 10 \mathrm{~mm} / \text { day) } \\
\text { [day/year] }(\mathrm{R} 10 \mathrm{~mm})\end{array}$ & $0.16^{*}$ & 0.049 & -0.063 & -0.037 \\
\hline p-value & 0.135 & 0.756 & 0.796 & 0.863 \\
\hline $\begin{array}{l}\text { Number of very heavy precipi- } \\
\text { tation days }(20 \mathrm{~mm} / \text { day) (R20 } \\
\mathrm{mm}) \text { [day/year] }\end{array}$ & $0.135^{*}$ & $0.057^{*}$ & -0.127 & $-0.137^{*}$ \\
\hline p-value & 0.005 & 0.038 & 0.464 & 0.028 \\
\hline
\end{tabular}

Table 3. Studied ecosystem classification in DMQ.

\begin{tabular}{|c|c|c|c|c|c|}
\hline Station/Code & Ecosystem Classification & $\begin{array}{l}\text { Altitudinal } \\
\text { Variation } \\
\text { (m.a.s.l.) }\end{array}$ & $\begin{array}{c}\text { Minimum } \\
\text { Annual } \\
\text { Temperature }\left({ }^{\circ} \mathrm{C}\right)\end{array}$ & $\begin{array}{c}\text { Maximum } \\
\text { Annual } \\
\text { Temperature }\left({ }^{\circ} \mathrm{C}\right)\end{array}$ & $\begin{array}{c}\text { Annual } \\
\text { Precipitation } \\
(\mathrm{mm})\end{array}$ \\
\hline Izobamba/M003 & Artificial urban areas & $2400-3100$ & 10 & 16 & 960 (Murray, 1997) \\
\hline Papallacta/M188 & $\begin{array}{l}\text { High montane evergreen } \\
\text { forest. Polylepis Upper } \\
\text { montane Andean north } \\
\text { forests Polylepis (Josse et } \\
\text { al., 2003) }\end{array}$ & $4100-2900$ & 6 & 17 & $\begin{array}{l}922 \text { (Baquero et } \\
\text { al., 2004; cited in } \\
\text { MECN, 2009) }\end{array}$ \\
\hline $\begin{array}{l}\text { Tomalón- } \\
\text { Tabacundo/ } \\
\text { MA2T }\end{array}$ & $\begin{array}{l}\text { Espinar dry montane } \\
\text { (Valencia et al., 1999), } \\
\text { Matorral semi humid mon- } \\
\text { tane forest (Valencia et al., } \\
\text { 1999) y (Baquero et al., } \\
\text { 2004) }\end{array}$ & $2000-3000$ & 5 & 18 & $\begin{array}{l}575 \text { (Josse et al., } \\
2003 \text {; cited in } \\
\text { MECN, 2009) }\end{array}$ \\
\hline
\end{tabular}




\subsection{Ecosystem description of the sample points}

The DMQ is characterized by a great climatic and orographic variety, with the northwestern tropical, desert in the Guayllabamba Valley, the inter-andean permanently clouded forest in the cold mountain to urbanized city of Quito between the mountains that surround it. Giving as result a wide variety of ecosystems. However, due to the nature of the research, daily station data available only describe three types of ecosystems -with enough confidence-, which are presented in Table 3.

\subsection{Generalized Extreme Value Distribu- tion}

Let $X_{1}, \ldots, X_{n}$ be a sequence of independent random variables, and let $M_{n}=\max \left\{X_{1}, \ldots, X_{n}\right\}$ the maximum (or minimum) values measured on a regular timeline, so $M_{n}$ represents the extreme values of the process in $\mathrm{n}$ time units of observation. For this data, and using a linear renormalization, the distribution of the set of $M_{n}$ is given by the Generalized Extreme Value (GEV), which has the form:

$$
G(z)=\exp \left\{-\left[1+\xi\left(\frac{z-\mu}{\sigma}\right)\right]^{-\frac{1}{\xi}}\right\}
$$

where $\left\{1+\xi\left(\frac{z-\mu}{\sigma}\right)>0\right\}$ and $(-\infty<\mu<\infty), \sigma>0$, $(-\infty<\xi<\infty)$ are the parameters of location, scale and shape respectively (Coles, 2004).

This distribution depends on the sign of $\xi$, if $\xi<0$ we have the Weibull distribution, usually associated with temperature data if $\xi=0$, we have the Gumbel distribution, and if $\xi>0$ it is a Fréchet distribution, commonly used to simulate the behavior of precipitation (García et al., 2012).

An advantage of GEVD is the possibility of a non-stationary model, allowing a time-dependent distribution by the parameter $\mu_{1}$ :

$$
\mu(t)=\mu_{0}+\mu_{1} t .
$$

The parameter $\mu_{1}$ corresponds to the change of the location parameter, and could simulate the increasing or decreasing effects of climate change on weather variables.

\subsection{Climate change models}

In order to simulate the behavior of climate change in the planet, Global Circulation Models (GCM) we- re implemented by supercomputers, with horizontal resolutions of $300 \mathrm{~km}$. In order to understand the behavior of the weather at smaller scales, there are Regional Climate Models (RCM), which work with scales of $50 \mathrm{~km}$ or less, allowing for more precise characteristics of the land surface and complicated mountainous topography, coastlines and the inclusion of small islands and peninsulas.

RCMs are very complete dynamic models, based on the physics of the climate system, and virtually represent all processes, interactions and feedbacks between climate systems and the components of the GCMs (PRECIS, 2004).

An example is PRECIS (Providing Regional Climates for Impacts Studies), which is a regional climate modeling system developed by the Hadley Centre of the Met Office in the United Kingdom. It is a free software that allows the use of highresolution data in impact, vulnerability and adaptation studies as recommended by the United Nations Framework Convention on Climate Change (Articles 4.1, 4.8 and 12.1).

PRECIS works with HadCM GCM model, which is forced by surface boundary conditions such as sea surface temperature and sea-ice fraction. It has two time periods: $1960-1990$ a base time or "control" period, used for comparisons with real data; and 2000-2100, period used for forecasting. According to the IPCC (2001), circulation models are suggested to work with the A2 and B2 future scenarios agreeing to the economic and productive behavior of the planet and the possible incorporation of clean technologies. Where B2 scenario describes a world with a greater emphasis on local solutions to economic, social and environmental sustainability than A2. Both should be considered equally right. The scenarios do not include additional climate initiatives. In this work, these two scenarios are used.

\section{Materials and methods}

\subsection{DGVE, return levels and confidence in- tervals with real data}

This study recorded maximum and minimum temperatures in four stations, which were the only available in to DMQ with sufficient temporal range (more than 30 years) and daily resolution; as shown in Table 1, their behavior and trends were calculated using R-Climdex (Serrano et al., 2012), and then 
used to calculate the climate change indexes shown in Table 2. With these outputs, and using the extReme software and DGVE functions, future behaviors were estimated of the maximum allowance for extreme events of rain and temperature, with return levels for 2, 5, 10, 15 and 20 years and confidence intervals of $95 \%$, for both A2 and B2 scenarios since 2012.

\subsection{Fitting PRECIS data for each scenario}

In order to determine the validity of PRECIS, its gridded outputs for temperature, were used in the "control" period from 1960 to 1990 and compared with similar temporal periods for each station. A linear correlation for both the observed data and the modeled by PRECIS was made, finding the slope, the intersection in the middle of the series and the $p$-value for each case and achieving a correction factor by the difference in to the middle of the studied series (Table 4).

\section{Results}

\subsection{Analysis of Maximum Temperatures by meteorological station}

\subsubsection{Izobamba}

In Figure 1 the behavior of the maximum monthly value of the daily maximum temperature (TXX) in Izobamba, analysis achieved by R-ClimDex is shown. The trend of $0.010 \mathrm{C}$ per year is statistically significant at $76.3 \%$ (Serrano et al., 2012).

Table 4. Correction factor by available meteorological station, between PRECIS time series and observed data, for temperature.

\begin{tabular}{|c|c|c|c|c|c|c|c|}
\hline \multicolumn{4}{|c|}{ Observed data } & \multicolumn{3}{|c|}{ Control PRECIS } & \multirow{2}{*}{$\begin{array}{c}\text { Correction factor } \\
\text { PRECIS-Observed data }\end{array}$} \\
\hline Station & Slope & p-value & Intersection & Slope & p-value & Intersection & \\
\hline M003 & $1,08 \mathrm{E}-05$ & 0,0089 & 11,93 & $4,13 \mathrm{E}-05$ & $8,27 \mathrm{E}-67$ & 11,64 & 0,294970646 \\
\hline M180 & $3,92 \mathrm{E}-05$ & $4,27 \mathrm{E}-14$ & 9,76 & $4,34 \mathrm{E}-05$ & $2,47 \mathrm{E}-45$ & 10,11 & $-0,352601947$ \\
\hline M120 & 1,6693E-04 & $2,19 \mathrm{E}-22$ & 11,93 & $4,50 \mathrm{E}-05$ & $1,45 \mathrm{E}-72$ & 10,16 & $-0,712912888$ \\
\hline
\end{tabular}

Figure 1. Behavior of annual maximum of daily maximum temperature (TXX) in Izobamba.

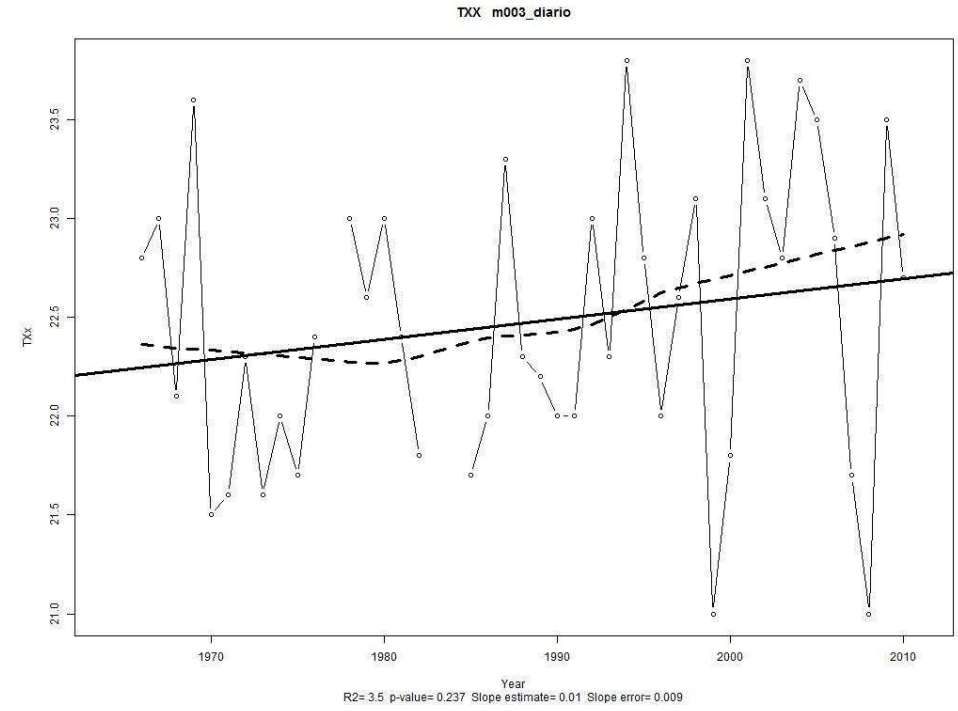

LA GRAnJa:Revista de Ciencias de la Vida 25(1) 2017:16-32.

(C) 2017, Universidad Politécnica Salesiana, Ecuador. 
Figure 2. Adjusting of the maximum annual value of daily maximum temperature (TXX) in Izobamba for DGVE Weibull type distribution. The first two upper graphs show the proper fit of the model, while the lower left and right graphs show the return periods with confidence limits of $95 \%$ (blue line) and the probability density distribution.

Probability Plot

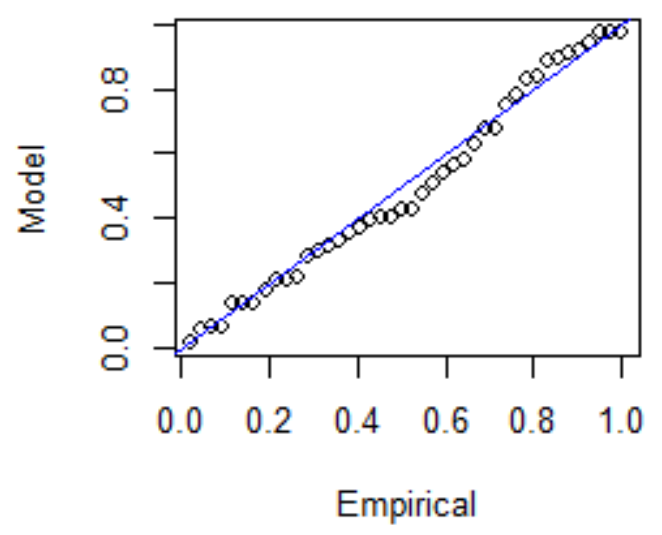

Return Level Plot

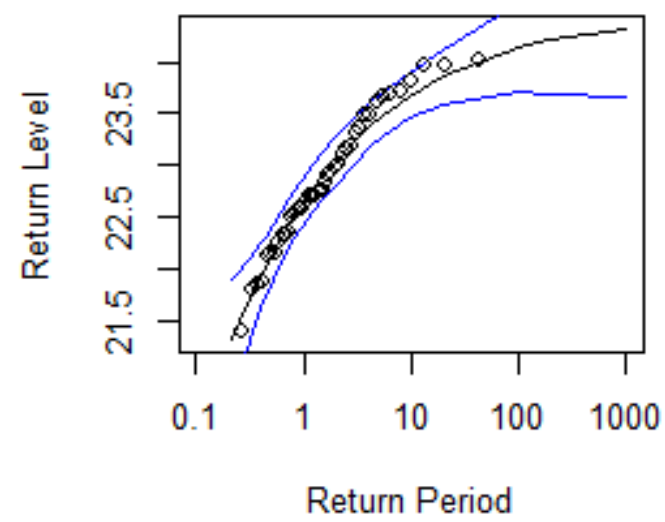

Figure 2 shows the data set to a covariant DGVE where the results, after the maximum likelihood method, indicate that the location parameter varies over time like: $\mu=22,65353(0,11592)+0,01 t$ the scale parameter is $\sigma=0,65709(0,08777)$, and the shape parameter is $\xi=-0,36045(0,14134)$, following a Weibull distribution. The maximum likelihood was 0.01303611 , and the $\mathrm{p}$-value has a significance value above $98 \%$. Values in parentheses indicate the standard deviations of each parameter.

Return values and confidence limits for the
Quantile Plot

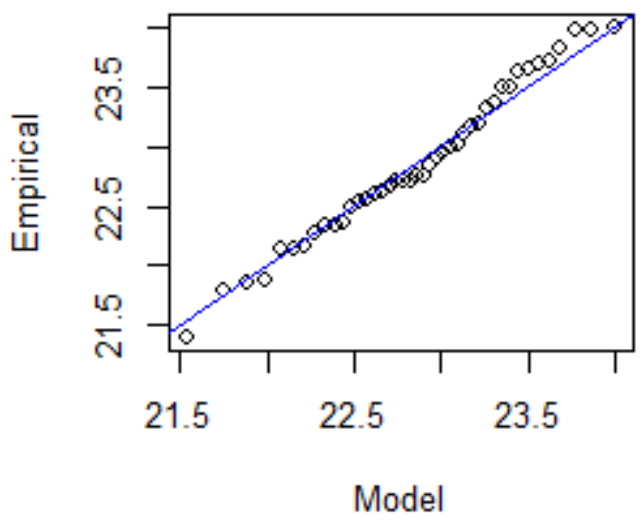

Density Plot

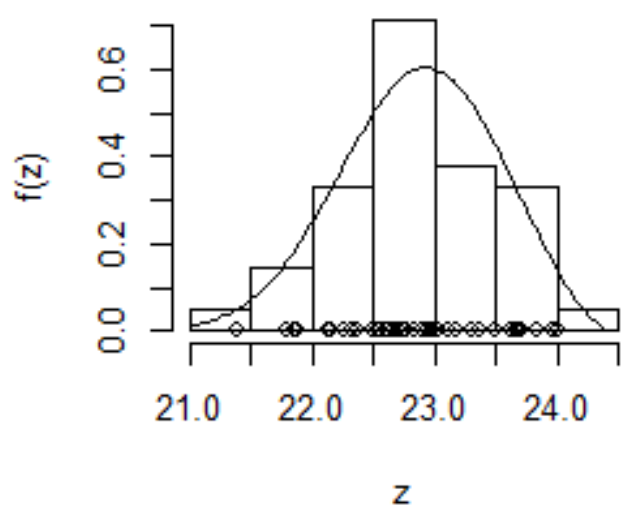

Izobamba data studied up to 100 years are presented in the lower part of Figure 2, but in detail, and for 2022 year are shown in Table 5 . The value of the shape parameter for all periods is $\xi=-0,3604(-0,61849,-0,10241)$. Also, the settings of trend data achieved with PRECIS for A2 and B2 scenarios are presented in Table 4 The value of the shape parameter for all periods is $\xi=-0,1751(-0,31983,0,02098)$ to $\mathrm{A} 2$; and $\xi=$ $-0,2264(-0,40246,-0,03666)$ to B2. 
Table 5. Return periods, return levels and confidence intervals at $95 \%$ for the actual data of maximum temperatures in Izobamba.

\begin{tabular}{cccccccccc}
\hline $\begin{array}{c}\text { Return } \\
\text { period } \\
\text { (years) }\end{array}$ & \multicolumn{3}{c}{ Observed } & \multicolumn{4}{c}{ PRECIS A2 } & \multicolumn{3}{c}{ PRECIS B2 } \\
\cline { 2 - 10 } & $\begin{array}{c}\text { Return level } \\
{\left[{ }^{\circ} \mathrm{C} / \text { day }\right]}\end{array}$ & $\begin{array}{c}\text { LI } \\
{\left[{ }^{\circ} \mathrm{C} / \text { day }\right]}\end{array}$ & $\begin{array}{c}\text { LS } \\
{\left[{ }^{\circ} \mathrm{C} / \text { day }\right]}\end{array}$ & $\begin{array}{c}\text { Return level } \\
{\left[{ }^{\circ} \mathrm{C} / \text { day }\right]}\end{array}$ & $\begin{array}{c}\text { LI } \\
{\left[{ }^{\circ} \mathrm{C} / \text { day }\right]}\end{array}$ & $\begin{array}{c}\text { LS } \\
{\left[{ }^{\circ} \mathrm{C} / \text { day }\right]}\end{array}$ & $\begin{array}{c}\text { Return level } \\
{\left[{ }^{\circ} \mathrm{C} / \text { day }\right]}\end{array}$ & $\begin{array}{c}\text { LI } \\
{\left[{ }^{\circ} \mathrm{C} / \text { day }\right]}\end{array}$ & $\begin{array}{c}\text { LS } \\
{\left[{ }^{\circ} \mathrm{C} / \text { day }\right]}\end{array}$ \\
\hline 2014 & 22.879 & 22.652 & 23.1144 & 23.133 & 22.91 & 23.3696 & 23.168 & 22.8978 & 23.4483 \\
2017 & 23.414 & 23.1986 & 23.6392 & 23.807 & 23.551 & 24.1132 & 23.9056 & 23.6147 & 24.2505 \\
2019 & 23.666 & 23.4628 & 23.9786 & 23.999 & 23.7303 & 24.3542 & 24.1082 & 23.8077 & 24.5028 \\
2022 & 23.781 & 23.5809 & 24.1296 & 24.185 & 23.9005 & 24.6095 & 24.2996 & 23.9878 & 24.7644 \\
2027 & 23.851 & 23.6515 & 24.2306 & 24.377 & 24.0736 & 24.9012 & 24.494 & 24.1674 & 25.0563 \\
2032 & 22.879 & 22.652 & 23.1144 & 24.503 & 24.1851 & 25.0895 & 24.6195 & 24.2809 & 25.2437 \\
\hline
\end{tabular}

Table 6. Return periods, return levels and confidence intervals at $95 \%$ for analyzed data and both A2 and B2 scenarios of PRECIS, for the maximum annual temperatures in Tomalón-Tabacundo.

\begin{tabular}{|c|c|c|c|c|c|c|c|c|c|}
\hline \multirow{2}{*}{$\begin{array}{l}\text { Return } \\
\text { period } \\
\text { (years) }\end{array}$} & \multicolumn{3}{|c|}{ Observed } & \multicolumn{3}{|c|}{ PRECIS A2 } & \multicolumn{3}{|c|}{ PRECIS B2 } \\
\hline & $\begin{array}{c}\text { Return level } \\
{\left[{ }^{\circ} \mathrm{C} / \text { day }\right]}\end{array}$ & $\begin{array}{c}\mathrm{LI} \\
{\left[{ }^{\circ} \mathrm{C} / \mathrm{day}\right]}\end{array}$ & $\begin{array}{c}\text { LS } \\
{\left[{ }^{\circ} \mathrm{C} / \text { day }\right]}\end{array}$ & $\begin{array}{c}\text { Return level } \\
{\left[{ }^{\circ} \mathrm{C} / \text { day }\right]}\end{array}$ & $\begin{array}{c}\mathrm{LI} \\
{\left[{ }^{\circ} \mathrm{C} / \mathrm{day}\right]}\end{array}$ & $\begin{array}{c}\text { LS } \\
{\left[{ }^{\circ} \mathrm{C} / \text { day }\right]}\end{array}$ & $\begin{array}{c}\text { Return level } \\
{\left[{ }^{\circ} \mathrm{C} / \text { day }\right]}\end{array}$ & $\begin{array}{c}\text { LI } \\
{\left[{ }^{\circ} \mathrm{C} / \text { day }\right]}\end{array}$ & $\begin{array}{c}\mathrm{LS} \\
{\left[{ }^{\circ} \mathrm{C} / \text { day }\right]}\end{array}$ \\
\hline 2014 & 27.7286 & 27.1488 & 28.3307 & 28.5509 & 28.2998 & 29.5172 & 28.0392 & 27.4989 & 28.0392 \\
\hline 2017 & 28.6298 & 28.0676 & 29.3502 & 29.2193 & 29.0496 & 29.5375 & 28.7569 & 28.2599 & 29.3245 \\
\hline 2019 & 28.858 & 28.3054 & 29.7135 & 29.3278 & 29.2666 & 29.6931 & 28.9228 & 28.4614 & 29.5541 \\
\hline 2022 & 29.0654 & 28.5221 & 29.9473 & 29.4081 & 29.2859 & 29.825 & 29.0671 & 28.6424 & 29.67 \\
\hline 2027 & 29.2674 & 28.7319 & 30.2188 & 29.4709 & 29.4015 & 29.7692 & 29.2013 & 28.8123 & 29.8465 \\
\hline 2032 & 29.3929 & 28.8606 & 30.4183 & 29.5028 & 29.4487 & 29.7336 & 29.2812 & 28.9124 & 29.9996 \\
\hline
\end{tabular}

\subsubsection{Tomalón-Tabacundo}

The same statistical treatment as performed to Izobamba was applied, and was recorded the highest slope of DMQ $\left(0.125^{\circ} \mathrm{C} /\right.$ year $)$ with a statistical significance of $0.999 \%$. By simulating the data with a covariant DGVE the maximum likelihood method indicate a temporal variation of the location parameter: $\mu=27,35713(0,29314)+0,125 t$, the scale parameter was $\sigma=1,07630(0,21311)$, and the shape parameter was $\xi=-0,33074(0,19109)$, showing that these data follow a Weibull distribution; the p-value was 0.1150664 . The return levels and confidence limits of the observed data and for the A2, B2 scenarios is presented in Table 6.

\subsubsection{Papallacta}

In the serie of the maximun value of maximun temperature there is a positive trend of $0.031^{\circ} \mathrm{C} /$ year, with a statistical significance of $0.89 \%$. The simulation a covariant DGVE and using the maximum likelihood method indicate that the location parameter varies over time as $\mu=19,39455(0,26281)+$ $0,031 t$, the scale parameter $\sigma=0,96090(0,19836)$, the shape parameter $\xi=-0,28744(0,22732)$, showing that these data follow a Weibull distribution, the value-p-value 0.2363144 , significant at $76 \%$ level. Comparison of return levels and confidence intervals for the two scenarios and the observed data is presented in Table 7. 
Table 7. Return periods, return levels and confidence intervals at $95 \%$ for analyzed data and both A2 and B2 scenarios of PRECIS for the next 20 years, for the maximum annual temperatures in Papallacta.

\begin{tabular}{cccccccccc}
\hline $\begin{array}{c}\text { Return } \\
\text { period } \\
\text { (years) }\end{array}$ & \multicolumn{3}{c}{ Observed } & \multicolumn{4}{c}{ PRECIS A2 } & \multicolumn{3}{c}{ PRECIS B2 } \\
\cline { 2 - 10 } & $\begin{array}{c}\text { Return level } \\
{\left[{ }^{\circ} \mathrm{C} / \text { day }\right]}\end{array}$ & $\begin{array}{c}\text { LI } \\
{\left[{ }^{\circ} \mathrm{C} / \text { day }\right]}\end{array}$ & $\begin{array}{c}\text { LS } \\
{\left[{ }^{\circ} \mathrm{C} / \text { day }\right]}\end{array}$ & $\begin{array}{c}\text { Return level } \\
{\left[{ }^{\circ} \mathrm{C} / \text { day }\right]}\end{array}$ & $\begin{array}{c}\text { LI } \\
{\left[{ }^{\circ} \mathrm{C} / \text { day }\right]}\end{array}$ & $\begin{array}{c}\text { LS } \\
{\left[{ }^{\circ} \mathrm{C} / \text { day }\right]}\end{array}$ & $\begin{array}{c}\text { Return level } \\
{\left[{ }^{\circ} \mathrm{C} / \text { day }\right]}\end{array}$ & $\begin{array}{c}\text { LI } \\
{\left[{ }^{\circ} \mathrm{C} / \text { day }\right]}\end{array}$ & $\begin{array}{c}\text { LS } \\
{\left[{ }^{\circ} \mathrm{C} / \text { day }\right]}\end{array}$ \\
\hline 2014 & 19.7288 & 19.2086 & 20.2856 & 20.0045 & 19.4826 & 20.6801 & 20.4026 & 19.9515 & 20.928 \\
2017 & 20.5654 & 20.0355 & 21.2828 & 21.231 & 20.4309 & 22.7266 & 21.2677 & 20.7114 & 22.1982 \\
2019 & 20.7845 & 20.2607 & 21.5991 & 21.6826 & 20.75 & 23.5557 & 21.5366 & 20.9423 & 22.5901 \\
2022 & 20.9868 & 20.468 & 21.8494 & 22.1763 & 21.0762 & 24.5801 & 21.8067 & 21.1655 & 23.0488 \\
2027 & 21.1874 & 20.6696 & 22.1613 & 22.7625 & 21.4322 & 25.9559 & 22.0995 & 21.3945 & 23.6352 \\
2032 & 21.314 & 20.7932 & 22.4003 & 23.1975 & 21.6749 & 27.083 & 22.2998 & 21.5419 & 24.0935 \\
\hline
\end{tabular}

Figure 3. Maximum annual daily temperatures expected for the next 10 years in the DMQ in the color bar. Horizontal data shows the Longitude, Vertical the Latitude. a) forecast using the observed trend with real data from the studied meteorological stations, b) forecast using the product of dynamic forcing trend calculated by PRECIS A2 scenario c) Forecast using the product calculated by the dynamic forcing B2 (optimistic) scenario of PRECIS trend.

a)

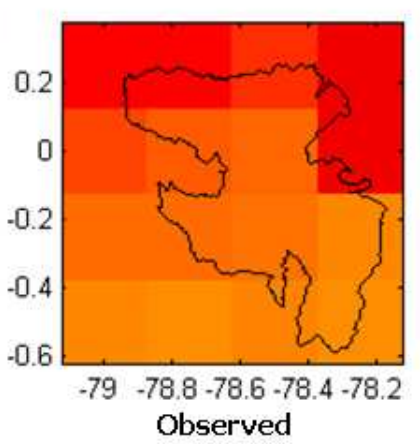

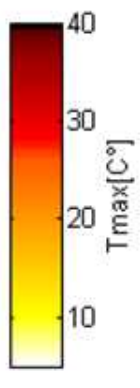

b)

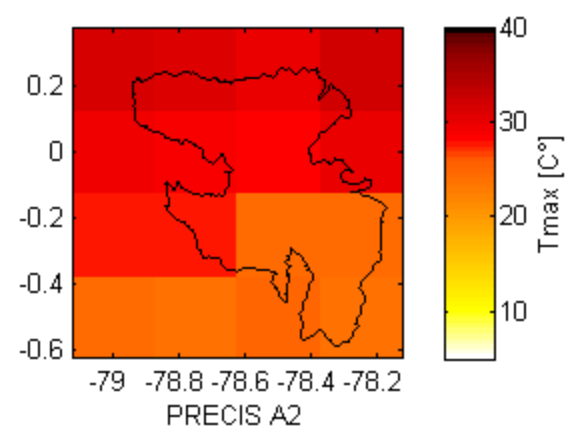

c)

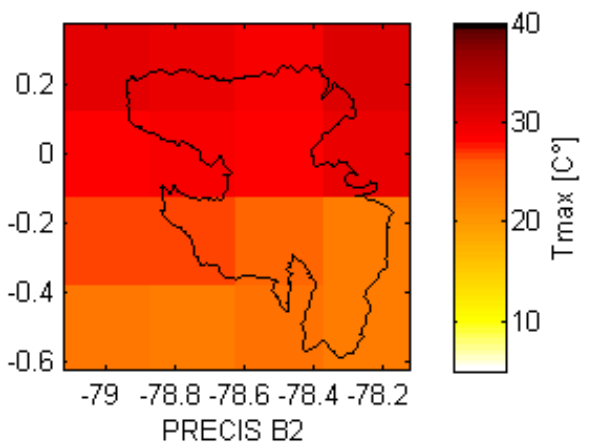


The GCM simulated data were regionalized using the technique of approaching averages, taking into account the annual mean temperature maps of the Ministry of Environment (MDMQ, 2011) and PRECIS model outputs, thus maps are presented with the resolution of this latter model. In Figure 3(a) shows the highest values of annual maximum temperatures that can be expected to 2032 year, these results take into account the dynamic forcing calculated by PRECIS scenarios A2 and B2, which are shown in Figure 3(b) and 3(c) respectively.

\subsection{Analysis of daily minimum temperatu- res for Izobamba, Tomalón-Tabacundo y Papallacta}

The behavior of the annual maximum values of minimum temperatures (early hours of dawn) for Izobamba station, located south of the DMQ is presented, into the series there is a positive trend of $0.03^{\circ} \mathrm{C}$ /year with a statistical significance of $75.7 \%$. By simulating the data with a covariant DGVE, the location parameter was $\mu=10,05092(0,13680)+$ $0,03 t$, the scale parameter was $\sigma=0,78644(0,09780)$, and the shape parameter $\xi=-0,22174(0,11901)$. Showing that these data follow a Weibull distribution. Also the test of maximum likelihood indicates that the p-value was 0,09103756 .

In Tomalón-Tabacundo the trend was $0.051^{\circ} \mathrm{C} /$ year, and the DGVE has a location parameter of $\mu=14,38173(0,29938)+0,051 t$, a scale parameter of $\sigma=1,07082(0,23624)$, and a shape parameter of $\xi=-0,27288(0,27655)$, in a Weibull distribution, the p-value was 0.3372716. Since in Papallacta, the trend is positive too: $0.067^{\circ} \mathrm{C} /$ year with a significance of $96.7 \%$. The return levels and confidence intervals for the two scenarios and the observed data for the three stations for 2032 year is presented in Table 8.

Similarly, the regional data of annual maximum values of minimum temperatures in the $\mathrm{DMQ}$, for real data and the A2, B2 scenarios are presented in Figure 4.

\subsection{Behavior of the heavy rainfall in Izo- bamba, Tomalón-Tabacundo and Pa- pallacta}

The behavior of maximum annual values of maximum precipitation days (above the 95 th percentile $=$
$20 \mathrm{~mm} /$ day) for Izobamba station, located south of the DMQ, shows a positive trend of $0.366 \mathrm{~mm} /$ year with a statistical significance of $96.7 \%$ (Figure 5).

However, in the case of precipitation, there was not detected a direct dynamic forcing producing its increase over time (IPCC, 2014), but the increase in extreme weather events in general. That is why we did not use PRECIS scenarios. Return levels and confidence intervals are calculated only with the observed data, as shown in Table 9.

By simulating covariant DGVE results achieved after the maximum likelihood method in Izombamba, indicates that the location parameter varies $\mu=52,16587(2,98138)+0,366 t$, the scale parameter $\sigma=17,45288(2,34374)$, the shape parameter $\xi=$ $0,18686(0,11512)$, showing that these data follow a Frechtel distribution with a p-value of 0.0622325 . The results are shown in Table 9(a).

In Tomalón-Tabacundo, the dryest region, the maximun precipitation has a negative trend of $-0.161 \mathrm{~mm} /$ year with a p-value of 0.649 , the location parameter was chosen as $\mu=$ $27,44210(2,31995)$, with a $\sigma=8,65550(1,98911)$, and $\xi=0,33574(0,22768)$, into a Frechtel distribution, the p-value was 0.02581635 (Table 9(b)).

In Papallacta there is another negative trend of $-0.473 \mathrm{~mm} /$ yer (p-value of 0.211 ). The DGVE has a location parameter of $\mu=52,81604(7,64252), \sigma=$ $34,79840(6,15202)$, and $\xi=0,24224(0,14866)$, in a Frechtel distribution with a p-value of 0.03283383 (Table 9(c)).

The regional data in Table 7 for maximum value per year of heavy precipitation into DMQ is presented in Figure 6.

\section{Conclusions and discussion}

\subsection{Behavior of temperatures and ecosyste- mic impacts in the DMQ}

In the DMQ were identified three types of threats related to climate change or climate variability: a statistically significant increase in the magnitude of both maximum and minimum temperatures and an increase in the frequency of heavy rainy days (Serrano et al., 2012). 
Figure 4. Annual maximum of daily Minimum Temperatures expected for 2032 year in the color bar. Horizontal data shows the Longitude, Vertical the Latitude. a) forecast using the observed trend of real data from the meteorological stations, b) forecast using the product of dynamic forcing trend calculated by the A2 scenario PRECIS, c) forecast using the trend product calculated by the dynamic forcing B2 scenario of PRECIS.

a)

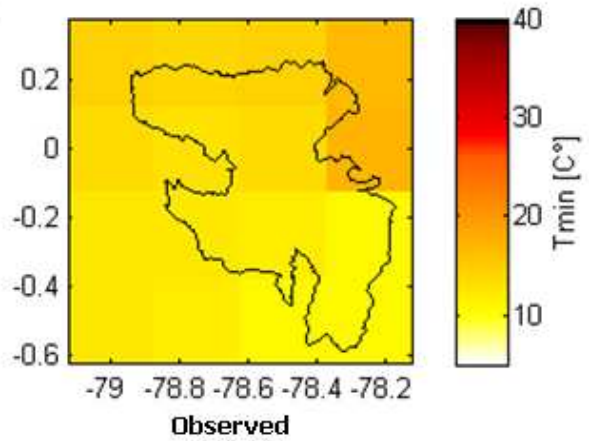

b)

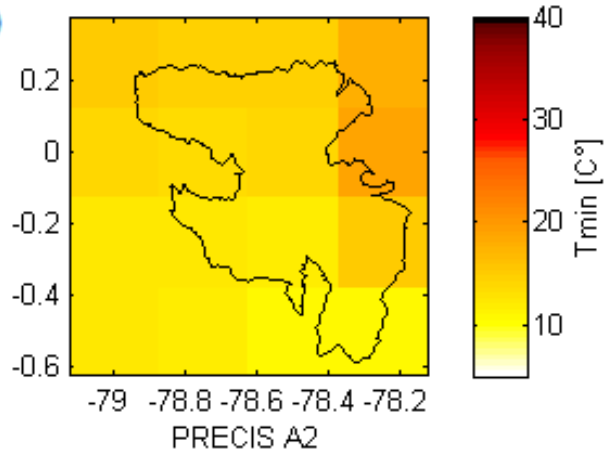

c)

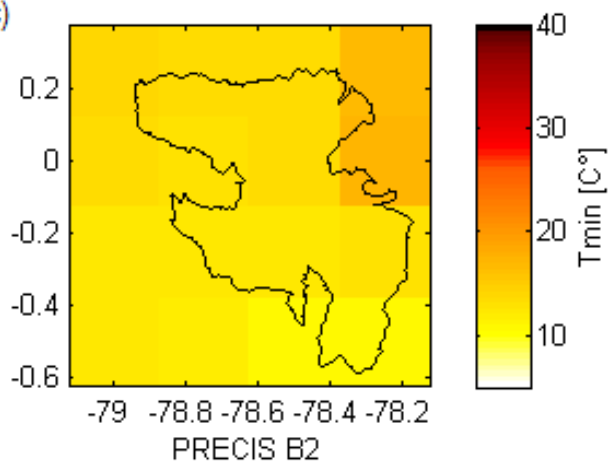

Figure 5. Annual behavior of the daily maximum precipitation values recorded since 1964 in the year 2011 in Izobamba.

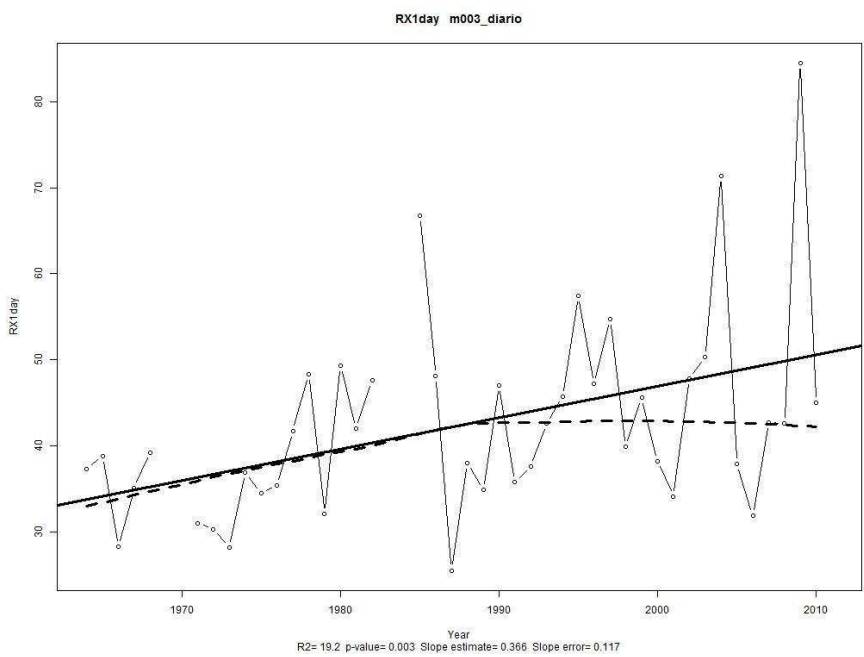


a) Izobamba

\begin{tabular}{|c|c|c|c|c|c|c|c|c|c|}
\hline \multirow{2}{*}{$\begin{array}{l}\text { Return } \\
\text { period } \\
\text { (years) }\end{array}$} & \multicolumn{3}{|c|}{ Observed } & \multicolumn{3}{|c|}{ PRECIS A2 } & \multicolumn{3}{|c|}{ PRECIS B2 } \\
\hline & $\begin{array}{c}\text { Return level } \\
{\left[{ }^{\circ} \mathrm{C} / \text { day }\right]}\end{array}$ & $\begin{array}{c}\mathrm{LI} \\
{\left[{ }^{\circ} \mathrm{C} / \mathrm{day}\right]}\end{array}$ & $\begin{array}{c}\mathrm{LS} \\
{\left[{ }^{\circ} \mathrm{C} / \mathrm{day}\right]}\end{array}$ & $\begin{array}{c}\text { Return level } \\
{\left[{ }^{\circ} \mathrm{C} / \text { day }\right]}\end{array}$ & $\begin{array}{c}\text { LI } \\
{\left[{ }^{\circ} \mathrm{C} / \text { day }\right]}\end{array}$ & $\begin{array}{c}\mathrm{LS} \\
{\left[{ }^{\circ} \mathrm{C} / \mathrm{day}\right]}\end{array}$ & $\begin{array}{c}\text { Return level } \\
{\left[{ }^{\circ} \mathrm{C} / \text { day }\right]}\end{array}$ & $\begin{array}{c}\mathrm{LI} \\
{\left[{ }^{\circ} \mathrm{C} / \mathrm{day}\right]}\end{array}$ & $\begin{array}{c}\mathrm{LS} \\
{\left[{ }^{\circ} \mathrm{C} / \text { day }\right]}\end{array}$ \\
\hline 2014 & 10.327 & 10.053 & 10.6168 & 10.5158 & 10.2428 & 10.7971 & 10.7593 & 10.465 & 11.0544 \\
\hline 2017 & 11.054 & 10.7566 & 11.4034 & 11.2254 & 10.9413 & 11.546 & 11.4875 & 11.2043 & 11.788 \\
\hline 2019 & 11.254 & 10.9494 & 11.6696 & 11.4139 & 11.1264 & 11.7798 & 11.6688 & 11.3901 & 11.9941 \\
\hline 2022 & 11.444 & 11.129 & 11.958 & 11.5891 & 11.2972 & 12.0264 & 11.8321 & 11.5578 & 12.2047 \\
\hline 2027 & 11.637 & 11.3068 & 12.2385 & 11.7641 & 11.465 & 12.2838 & 11.989 & 11.7192 & 12.4346 \\
\hline 2032 & 11.761 & 11.418 & 12.4268 & 11.8753 & 11.5697 & 12.4345 & 12.087 & 11.818 & 12.5507 \\
\hline
\end{tabular}

b) Tomalón-Tabacundo

\begin{tabular}{cccccccccc}
\hline Return & \multicolumn{3}{c}{ Observed } & \multicolumn{3}{c}{ PRECIS A2 } & \multicolumn{3}{c}{ PRECIS B2 } \\
\cline { 2 - 10 } $\begin{array}{c}\text { period } \\
\text { (years) }\end{array}$ & $\begin{array}{c}\text { Return level } \\
{\left[{ }^{\circ} \mathrm{C} / \text { day }\right]}\end{array}$ & $\begin{array}{c}\text { LI } \\
{\left[{ }^{\circ} \mathrm{C} / \text { day }\right]}\end{array}$ & $\begin{array}{c}\text { LS } \\
{\left[{ }^{\circ} \mathrm{C} / \text { day }\right]}\end{array}$ & $\begin{array}{c}\text { Return level } \\
{\left[{ }^{\circ} \mathrm{C} / \text { day }\right]}\end{array}$ & $\begin{array}{c}\text { LI } \\
{\left[{ }^{\circ} \mathrm{C} / \text { day }\right]}\end{array}$ & $\begin{array}{c}\text { LS } \\
{\left[{ }^{\circ} \mathrm{C} / \text { day }\right]}\end{array}$ & $\begin{array}{c}\text { Return level } \\
{\left[{ }^{\circ} \mathrm{C} / \text { day }\right]}\end{array}$ & $\begin{array}{c}\text { LI } \\
{\left[{ }^{\circ} \mathrm{C} / \text { day }\right]}\end{array}$ & $\begin{array}{c}\text { LS } \\
{\left[{ }^{\circ} \mathrm{C} / \text { day }\right]}\end{array}$ \\
\hline 2014 & 14.7552 & 14.16747 & 15.40656 & 14.7282 & 14.04727 & 15.50257 & 14.9877 & 14.30136 & 15.67958 \\
2017 & 15.6998 & 15.09104 & 16.54288 & 16.0592 & 15.22647 & 17.44137 & 16.055 & 15.39729 & 16.82908 \\
2019 & 15.95 & 15.35243 & 16.86408 & 16.4696 & 15.58255 & 18.02369 & 16.3168 & 15.68436 & 17.25251 \\
2022 & 16.1824 & 15.59416 & 17.16913 & 16.8801 & 15.92611 & 18.6907 & 16.5512 & 15.94356 & 17.48822 \\
2027 & 16.4141 & 15.82815 & 17.58124 & 17.3233 & 16.27861 & 19.5283 & 16.7759 & 16.19098 & 17.76637 \\
2032 & 16.5611 & 15.96987 & 17.90907 & 17.6253 & 16.50622 & 20.17527 & 16.9135 & 16.3407 & 17.9754 \\
\hline
\end{tabular}

c) Papallacta

\begin{tabular}{|c|c|c|c|c|c|c|c|c|c|}
\hline \multirow{2}{*}{$\begin{array}{l}\text { Return } \\
\text { period } \\
\text { (years) }\end{array}$} & \multicolumn{3}{|c|}{ Observed } & \multicolumn{3}{|c|}{ PRECIS A2 } & \multicolumn{3}{|c|}{ PRECIS B2 } \\
\hline & $\begin{array}{c}\text { Return level } \\
{\left[{ }^{\circ} \mathrm{C} / \text { day }\right]}\end{array}$ & $\begin{array}{c}\mathrm{LI} \\
{\left[{ }^{\circ} \mathrm{C} / \mathrm{day}\right]}\end{array}$ & $\begin{array}{c}\mathrm{LS} \\
{\left[{ }^{\circ} \mathrm{C} / \mathrm{day}\right]}\end{array}$ & $\begin{array}{c}\text { Return level } \\
{\left[{ }^{\circ} \mathrm{C} / \text { day }\right]}\end{array}$ & $\begin{array}{c}\mathrm{LI} \\
{\left[{ }^{\circ} \mathrm{C} / \mathrm{day}\right]}\end{array}$ & $\begin{array}{c}\text { LS } \\
{\left[{ }^{\circ} \mathrm{C} / \text { day }\right]}\end{array}$ & $\begin{array}{c}\text { Return level } \\
{\left[{ }^{\circ} \mathrm{C} / \text { day }\right]}\end{array}$ & $\begin{array}{c}\mathrm{LI} \\
{\left[{ }^{\circ} \mathrm{C} / \mathrm{day}\right]}\end{array}$ & $\begin{array}{c}\text { LS } \\
{\left[{ }^{\circ} \mathrm{C} / \text { day }\right]}\end{array}$ \\
\hline 2014 & 9.098 & 8.51747 & 9.09802 & 11.3319 & 9.92041 & 11.33188 & 9.8874 & 9.17342 & 10.67584 \\
\hline 2017 & 9.8408 & 9.29491 & 10.59829 & 12.9631 & 11.83807 & 14.12185 & 10.9109 & 10.12034 & 12.13227 \\
\hline 2019 & 10.0219 & 9.4964 & 10.79966 & 13.312 & 12.27014 & 14.68806 & 11.1987 & 10.40246 & 12.48641 \\
\hline 2022 & 10.1835 & 9.67933 & 10.96891 & 13.6047 & 12.64676 & 14.92382 & 11.4739 & 10.6679 & 12.9048 \\
\hline 2027 & 10.338 & 9.855 & 11.19093 & 13.8665 & 12.99694 & 15.09987 & 11.7569 & 10.93114 & 13.45406 \\
\hline 2032 & 10.4323 & 9.96152 & 11.36773 & 14.0171 & 13.20499 & 15.22524 & 11.9416 & 11.09534 & 13.88822 \\
\hline
\end{tabular}

Table 8. Return periods, return levels and confidence intervals at $95 \%$ for both scenarios A2 and B2 of PRECIS for the next 20 years, for the minimum annual temperatures in a) Izobamba b) Tomalón-Tabacundo c) Papallacta.

LA GRANJA:Revista de Ciencias de la Vida 25(1) 2017:16-32.

(C)2017, Universidad Politécnica Salesiana, Ecuador. 
a)

\begin{tabular}{ccccc}
\hline Return period [years] & Year & Return level [mm/day] & IL 95\% [mm/day] & SL 95\% [mm/day] \\
\hline 2 & 2014 & 58.7867 & 52.3806 & 66.39552 \\
5 & 2017 & 82.381 & 71.81226 & 98.9752 \\
7 & 2019 & 91.2272 & 78.53774 & 113.82874 \\
10 & 2022 & 100.9893 & 85.58649 & 131.11258 \\
15 & 2027 & 112.6984 & 93.54083 & 152.2947 \\
20 & 2032 & 121.4659 & 99.1595 & 169.26421 \\
\hline
\end{tabular}

b)

\begin{tabular}{ccccc}
\hline Return period [years] & Year & Return level [mm/day] & IL 95\% [mm/day] & SL 95\% [mm/day] \\
\hline 2 & 2014 & 30.8179 & 25.83315 & 37.5405 \\
5 & 2017 & 44.3192 & 35.40184 & 61.89684 \\
7 & 2019 & 49.9595 & 38.958 & 73.53879 \\
10 & 2022 & 56.5417 & 42.74972 & 88.82883 \\
15 & 2027 & 64.9244 & 19.16253 & 110.68628 \\
20 & 2032 & 71.5448 & 13.47774 & 71.54475 \\
\hline
\end{tabular}

c)

\begin{tabular}{ccccc}
\hline Return period [years] & Year & Return level [mm/day] & IL 95\% [mm/day] & SL 95\% [mm/day] \\
\hline 2 & 2014 & 66.1534 & 49.78686 & 86.86547 \\
5 & 2017 & 115.7551 & 87.95392 & 167.84057 \\
7 & 2019 & $135.1206 "$ & 101.41638 & 201.95179 \\
10 & 2022 & 156.9403 & 115.64823 & 243.90614 \\
15 & 2027 & 183.7016 & 131.87326 & 300.17372 \\
20 & 2032 & 204.1415 & 143.44968 & 143.44968 \\
\hline
\end{tabular}

Table 9. Return periods, return levels and confidence intervals at $95 \%$ for the actual data of maximum heavy rainfall in a) Izobamba, b) Tomalón-Tabacundo, c) Papallacta. 
Figure 6. Possible values of maximum daily precipitation forecasts for the next 10 years in the DMQ year in the color bar. Horizontal data shows the Longitude, Vertical the Latitude. The figure shows the values of extreme events by day expected during this period, since Table 7 .

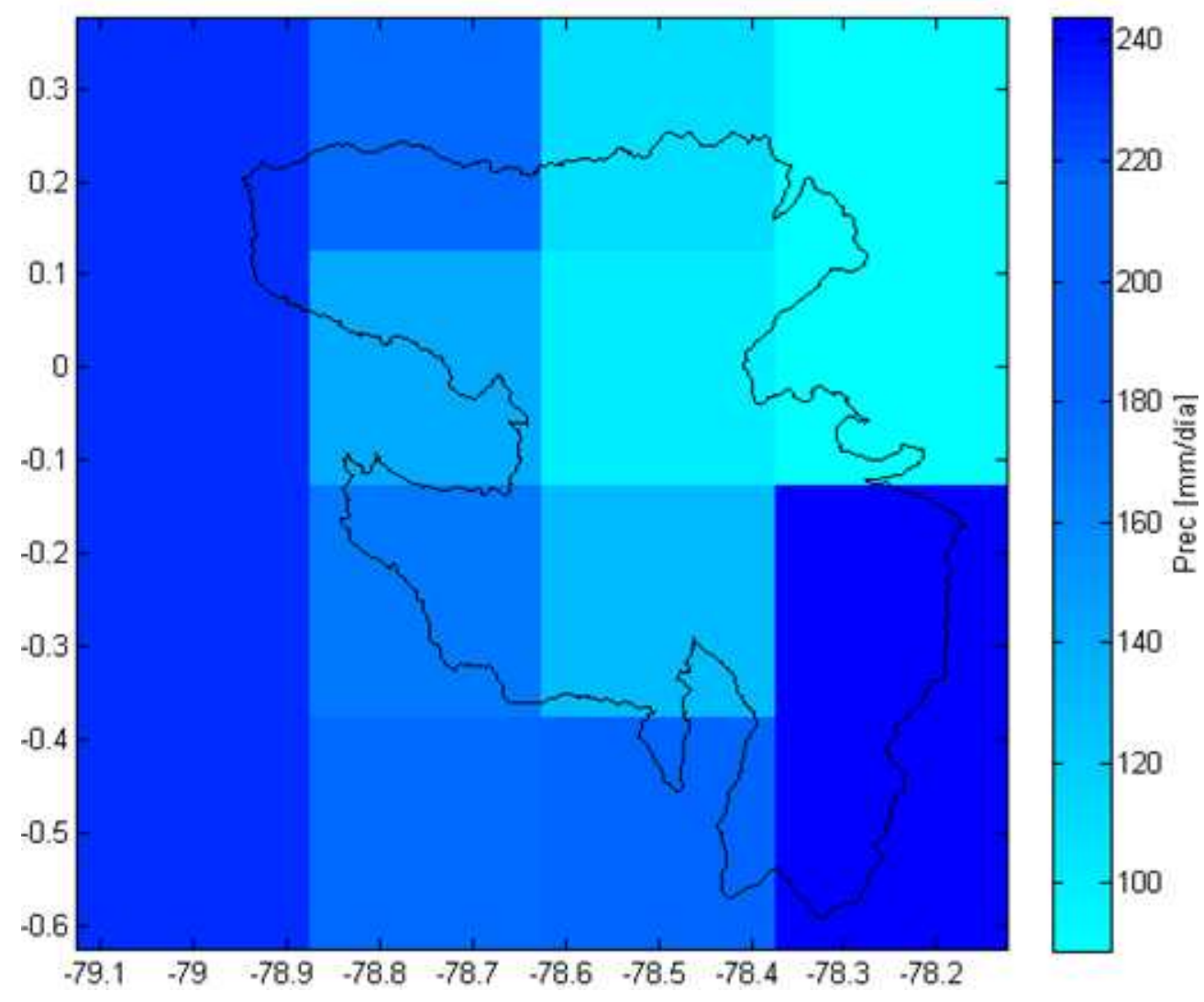

The first part of this study, was aimed to know the intensity of extreme events of the minimum and maximum temperatures in the near future $(2032$ year), using DGVE distributions which indicated that the best fit to the temperature values was given by a Weibull covariant distribution i.e. involving a forcing behavior data. Thus, we have worked with the atmospheric forcing presented in PRECIS for A1 and B1 scenarios. In consequence, this study used both: a dynamic and statistical prediction.

Results show that for 2032 year, in the southern area (Izobamba), where the average daily maximum temperature is $14.6^{\circ} \mathrm{C}$, it will be possible observe extreme events such as temperatures up to $23.7^{\circ} \mathrm{C}$, and according to the A2 and B2 scenarios temperatures as high as $24.3^{\circ} \mathrm{C}$ and $24.2^{\circ} \mathrm{C}$ respectively could be observed, i.e. an eventual increase of about $10^{\circ}$ over the average. It is expected to occur in the months of August and September, which corresponding to the dry season in Quito.
In the southeastern region (Papallacta) where the average daily maximum temperature is $14.4^{\circ} \mathrm{C}$, it is expected to register extreme events of $21^{\circ} \mathrm{C}$, and according to the A2 and B2 models $21.8^{\circ} \mathrm{C}$ and 21.1 respectively, about $7^{\circ} \mathrm{C}$ above average temperature. While in the north-east, the warmest region in $\mathrm{DMQ}$, averaging $21.6^{\circ} \mathrm{C}$, in 10 years it is possible to find extreme values up to $29^{\circ} \mathrm{C}$ and using the A2 and $\mathrm{B} 2$ scenarios of $29.4^{\circ} \mathrm{C}$, and $29^{\circ} \mathrm{C}$ respectively, i.e. $8^{\circ} \mathrm{C}$ more than average.

In the case of minimum temperatures, in Izobamba whose average daily minimum temperatures are $6^{\circ} \mathrm{C}$, is expected to record extreme events of $11.4^{\circ} \mathrm{C}, 11.6^{\circ} \mathrm{C}$ and $11.8^{\circ} \mathrm{C}$ according to statistical data and scenarios A2 and B2 respectively, an increase of nearly $7^{\circ}$. In Papallacta, with an average lowest temperature of $5.5^{\circ} \mathrm{C}$, it is expected to have extreme temperatures as low as $10.1^{\circ} \mathrm{C}$ and $\mathrm{A} 2$ and $\mathrm{B} 2$ respectively $13.6^{\circ} \mathrm{C}$ and $11.4^{\circ} \mathrm{C}$ models, an increase of more than $8^{\circ} \mathrm{C}$. Also, in the warmest re- 
gion of the DMQ, where station Tabacundo Tomalon is located, has an average of $9.11^{\circ} \mathrm{C}$, and the model can be registered $16.2^{\circ} \mathrm{C}, 16.8^{\circ} \mathrm{C}$ and $16.5^{\circ} \mathrm{C}$ according to statistical trend and the two scenarios A2 and $\mathrm{B} 2$, i.e. more than $7^{\circ} \mathrm{C}$ for the next 10 years.

It should be noted that these values are possible extreme temperature events, whose frequency is casual, but the intensity has been shown to consistently rise may experience extreme events between 6 and $10^{\circ} \mathrm{C}$ more than average temperatures to which ecosystems are already accustomed.

\subsection{Behavior of heavy precipitation}

In the case of the precipitation DGVE indicate that the better option is to use a no covariant Fretchel distribution. In Izobamba, registered as the rainiest region, with a mean daily rainfall of $6.8 \mathrm{~mm}$, it is expected to register single events to up $100 \mathrm{~mm} /$ day, 14 times more than the average. The southeastern area represented by Papallacta has daily rainfall averages $3.7 \mathrm{~mm} /$ day, and in the next 10 years may register $156 \mathrm{~mm} /$ day, i.e. 42 times more. This phenomena occurs because Papallacta has historically registered record rainfall of $183 \mathrm{~mm} /$ day and 160 $\mathrm{mm} /$ day on 27 and 25 March 2003 respectively. Therefore it is very likely that the coming years will see a similar events of this magnitude.

As for the northeast, where the station TomalonTabacundo is located, average rainfall of 4.3 $\mathrm{mm} /$ day and can record maximum of $56.5 \mathrm{~mm} /$ day are recorded. It should be noted that in this area the rains are often scarce, and there is a tendency to decrease precipitation and hence the hardening of dry regime.

\subsection{Ecosystem impact}

Because the DMQ have varied ecosystems with well defined characteristics, it becomes clear that these areas are affected differently.

On what it refers to the increase in minimum temperatures, even though it is a measure generally taken in the early hours of the morning, it is a direct measuring of warm nights. And it would be an indicator of potentially harmful effects by the lack of night cooling and main contributor of heat stress in animals and plants, especially those located in the transition zone of the paramo and are not adapted to these conditions. Also, it is noted that besides the presence of greenhouse gases that increase nightti- me temperatures, must be added the heat island effect, which must be taken into account in all sampling points, as the effects urbanization resulting in increased heat released during the night by modern infrastructure.

The increase in maximum temperatures, usually achieved at noon, directly affecting the adaptability of animal and plant species, including humans; because in a context of physical stress, coupled with high temperatures can be triggered death. Also, this indicator can also be interpreted as a measure of greater or lesser heliophany cloud cover, which can also favor the drought (Frich, 1999).

Also in the context of climate change, greenhouse gases favor the hydrological cycle and collaborating nucleation of water vapor into rain. While the increase of temperature favors the greatest amount of water vapor available, and hence is generated more intense precipitation. Those ecosystems that have more absorbency due to its vegetation cover would not be as affected by these sporadic events, although the edges urbanized city located in areas at risk by landslides are. Furthermore, it is noted that in the dry Northeast of DMQ has identified a negative trend in the presence of rain, which could result in the tightening of dry conditions in the area, affecting mainly to their biodiversity (Riebeek, 2005).

On the behavior of disease vectors, investigations of Rodriguez and Buitrón (20014) had been established that the increase of temperature and humidity favors the occurrence of diseases produced by insect vectors such as Anopheles mosquitoes and Aedes, responsible for the transmission of malaria and dengue. It was reported in 2010, in the provinces of Carchi (300- 4.723 m.a.s.l.) and Imbabura (1200 a 3000 m.a.s.l.) seven cases of dengue fever were confirmed, since National Institute of Hygiene Izquieta Perez (INHIP). Aedes currently aegypti is able to survive between 1,500 and 1,700 meter, meanwhile Varsovia Cevallos (El Comercio, 2010) conclude that under certain conditions of microclimate the mosquito could adapt to Quito and therefore could be cases of dengue, as happened in Galapagos in 2002 where the disease first and then the vector was reported. Ramirez et al. (2009), estimated that $34 \%$ of the world population would be at risk of contracting dengue. In Ecuador $70 \%$ of its territory is favorable for the presence of Aedes aegypti. 


\section{Acknowledgements}

This research was funded by the Climate Development Knowledge Network-CDKN within the Vulnerability Study DMQ. And it was done under the direction of Stokolm Eviroment-SEI Institute, the University Network for Climate Change represented by the Polytechnic National-EPN, the Pontifical Catholic University the Ecuador-PUCE and the Research Modeling Environment Center CIMA-UPS Salesian Polytechnic University. It also appreciated the product management and validation of the Secretariat of the Environment of Illustrious Metropolitan District of Quito, and to MAE (Ministry of Environment) an INAMHI for the data.

\section{References}

Baquero, F., R. Sierra, L. Ordoñez, M. Tipán, L. Espinoza, M. Ribera and P. Soria. 2004. La Vegetación de los Andes del Ecuador. Memoria explicativa de los mapas de vegetación potencial y remanente de los Andes del Ecuador a escala 1:250.000 y del modelamiento predictivo con especies indicadoras.

Cáceres, L., G. Mejía and Ontaneda. 1998. Evidencias del cambio climático en Ecuador. Bull. Inst. fr. Étudesandines. 27(3):547-556.

Coles, Stuart. 2004. S-plus functions for extreme value modeling: An accompaniment to the book an introduction to statistical modeling of extreme values. http://www.stats.bris.ac.uk/masgc/ismev/u ses.ps

El Comercio. 2010. El mosquito del dengue sí se adapta a Quito. 22 de marzo. http:/ / www.elcomercio.com/actualidad/mo squito-del-dengue-adapta-quito.html

Frich, P. 1999. REWARD-A Nordic Collaborative Project. Annex of Meeting of the Joint $\mathrm{CCl} /$ CLIVAR Task Group on Climate Indices, Bracknell, UK, 2-4 September 1998. World Climate Data and Monitoring Programme.

García, O. Rafael Cueto, N. Santillan Soto, S. Ojeda Benitez and M. Quintero Nuñez. 2012. Escenarios de temperaturas extremas en Mexicali, México bajo condiciones de cambio climático. páginas 349-358.
Gilleland, Eric and Richard W. Katz. 2005. Extremes Toolkit (extRemes): Weather and Climate Applications of Extreme Value. National Science Foundation (NSF) through the National Center for Atmospheric Research (NCAR) Weather and Climate Impact Assessment Science Initiative, with additional support from the NCAR Geophysical Statistics Project (GSP).

IPCC. 2001. Climate Change 2001: The Scientific Basis. Contribution of Working Group I to the Third Assessment Report of the Intergovernmental Panel on Climate Change [Houghton, J.T., Y. Ding, D.J. Griggs, M. Noguer, P.J. van der Linden, X. Dai, K.]

IPCC. 2014. Climate Change 2014: Synthesis Report. Contribution of Working Groups I, II and III to the Fifth Assessment Report of the Intergovernmental Panel on Climate Change [Core Writing Team, R.K. Pachauri and L.A. Meyer (eds.)]. IPCC, Geneva, Switzerland. page 151.

Josse, C., G. Navarro, P. Comer, R. Evans, D. FaberLangendoen, M. Fellows, G. Kittel, S. Menard, M. Pyne, M. Reid, K. Schulz, K. Snow and J. Teague. 2003. Ecological Systems of Latin America and the Caribbean: A Working Classification of Terrestrial Systems. NatureServe. Arlington, VA.

Karl, T., N. Nicholls and A. Ghazi. 1999. Clivar/gcos/wmo workshop on indices and indicators for climate extremes: Workshop summary. Climatic Change. 42:3-7.

Martínez, R., D. Ruiz, V. Marcos, M. Andrade, L. Blacutt, P. Daniel, et al. 2009. Synthesis of the climate of the tropical Andes.

MDMQ-Secretaría de Ambiente. 2011. Memoria Técnica del Mapa de Cobertura Vegetal del Distrito Metropolitano de Quito (DMQ). Quito.

MECN. 2009. Ecosistemas del Distrito Metropolitano de Quito (DMQ). Serie de Publicaciones del Museo Ecuatoriano de Ciencias Naturales (MECN)-Fondo Ambiental del MDMQ. Publicación Miscelánea (6):1-51. Imprenta Nuevo Arte. Quito, Ecuador. 
Murray, Sharon. 1997. Urban and Peri-Urban Forestry in Quito, Ecuador: a Case-Study. Forestry Department. Food and Agriculture Organization of the United Nations. Rome.

Nieto, J., R. Martínez, J. Regalado and F. Hernández. 2002. Análisis de tendencias de series de tiempo oceanográficas y meteorológicas para determinar evidencias de cambio climático en la costa del Ecuador. Acta oceanográfica del Pacífico. 11(1):17-21.

Peterson, T. 2001. Report on the activities of the working group on climate change detection and related rapporteurs 1998-2001. WMO, Rep. WCDMP-47, WMO-TD 1071. página 143. Geneve, Switzerland.

PRECIS. 2004. The PRECIS Handbook, Generating High Resolution Climate Change Scenarios using PRECIS. This handbook was published jointly by the UNDP and the Hadley Centre.

Ramírez, M. G. Zepeda, H. E. VelascoMondragón, C. Ramos, J. E. Peñuelas, et al. 2009. Caracterización clínica y epidemiológica de los casos de dengue: experiencia del Hospital General de Culiacán, Sinaloa, México. Rev. Panamá Salud Pública 2009. 25:16-23.

Riebeek, Holli. 2005. The Rising Cost of Natural Hazards. Earth Observatory.

Rodríguez, A. and M. Buitrón. 2015. Enfermedades sensibles al clima en el Distrito Metropolitano de Quito, un análisis temporal en el periodo 2001-2010. La Granja: Revista de Ciencias de la Vida. 21(1):16-33.

Samaniego, J. 2009. Cambio climático y desarrollo en América Latina y el Caribe: una reseña. CEPAL, Santiago, documento de Proyecto.
Serrano, S., D. Zuleta, V. Moscoso, P. Jácome, E. Palacios y M. Villacís. 2012. Análisis estadístico de datos meteorológicos mensuales y diarios para la determinación de variabilidad climática y cambio climático en el Distrito Metropolitano de Quito.La Granja. 16(2):23-47. ISSN: 1390-3799.

United Nations. 1995. Framework Convention on Climate Change. Conference of the parties. First session. Berlin.

Valencia, R., C. Cerón, W. Palacios and R. Sierra. 1999. Las Formaciones Naturales de la Sierra del Ecuador. Propuesta Preliminar de un Sistema de Clasificación de Vegetación para el Ecuador Continental. Proyecto INEFAN/ GEF-BIRF y EcoCiencia. páginas 79-108. Quito, Ecuador.

Villacís, M., F. Vimeux and J. Taupin. 2008. Analysis of the climate controls on the isotopic composition of precipitation (d18o) at nuevo rocafuerte, $74.5^{\circ} \mathrm{W}, 0.9^{\circ} \mathrm{S}, 250 \mathrm{~m}$, Ecuador. Comptes Rendus Geoscience. 340:1-9.

Villacís, M., A. Fernández, J.C. Pouget and M. Escobar. 2012. Impactos del cambio climático en el sector agua durante los últimos 30 años se identificación de los aspectos que constituyen la vulnerabilidad. Estudio de Vulnerabilidad del DMQ (not published).

Zambrano-Barragán, C., O. Zevallos, M. Villacís and D. Enriquez. 2010. Quito's climate change strategy: A response o climatic change at the metropolitan district of Quito, Ecuador. Resilient Cities: Cities and Adaptation to Climate Change. 